\title{
Chapter 13. The Ways of the Land-Tree: Mapping the North Pentecost Social Landscape
}

\author{
John P. Taylor
}

On a sunny afternoon, in the shade of a canopy of corrugated iron, beside a smoking fireplace on which green bananas were slowly roasting, my tama (father) and ratahigi ('chief'), Ruben Todali, talked to me about the history of Pentecost Island. He told me that in the past, many centuries before the arrival of tuturani (whites, foreigners) like myself, the people of North Pentecost could not speak. They communicated by way of designs that they described into the ground with their fingers. Instead of people, the sentient and mobile rocks and stones were talkative. ${ }^{1}$ The dark soil of the hills and valleys also spoke. So too did the winds, the rain, and the salt water that lapped against the sand and coral of the island's coast. But some time ago this situation reversed, so now it is people who talk, while the land, winds, rain and sea remain wordless. Nowadays, said Ruben, people sometimes said of their island, 'We must speak for the land, because the land cannot speak for itself' (from an interview with Jif Ruben Todali, Avatvotu, May 1999).

This intimate connection between people, land and language - of language as having somehow vacated the environment for the mouths of people - is echoed in the Raga words 'Sia Raga'. Raga speakers (see below) use this pronominal phrase when they wish to express a shared identity of language, land and alengan vanua ('ways of the place'). The word 'sia' means 'earthquake', and in this specific context refers to a seismic jolt known to have taken place many millennia ago, which caused the island's emergence from under the sea. 'Raga' refers to the Raga language, and also, in that language, to the island of Pentecost itself. In this paper I use the term Sia Raga to designate the Raga speakers of North Pentecost, being those people who claim ancestral connections to bwatun vanua ('foundation places') in the Raga-speaking region of North Pentecost, and who express that connection through shared links of land, kinship, language and culture. $^{2}$

Pentecost is a long narrow island stretching some 63 kilometres north to south and 12 kilometres across at its widest point. It is home to five distinctive vernacular languages (Tryon 1996: 170). The Raga language group has the highest number of speakers on the island-roughly 6,000. The area in which Raga is the defining language extends approximately $20 \mathrm{kms}$ southwards from the northern tip to Tasvarongo village, and also includes areas of South Maewo, the 
island immediately to the north of Pentecost. The least elevated part of the island, called Ahivo ('at down'), is the extreme northern tip. Here, more than 1,200 people reside in an area of about six square kilometres, making it the most heavily populated region of the island. The majority of other people live in villages of varying size, from as many as 2-300 to a single household. These are dotted mainly along the western coast, particularly within the Hurilau and Lolkasai districts, or across the inland central plateau of Aute. People also reside on the alluvial regions of the eastern coast at Aligu, either side of the main village of Renbura. Generally speaking, within the Raga-speaking region, hamlets are encountered with lessening frequency the further one travels southwards ('upwards', in local idiom), especially inland beyond the crescent-shaped west coast Bay of Loltong. Here, the terrain becomes increasingly rough, and overland travel more difficult.

As Lissant Bolton has observed, for ni-Vanuatu, the landscape is not considered a stable entity. Rather, she suggests, 'in a volcanic zone where islands rise and fall under the ocean, and where hurricanes, earthquakes and even volcanic eruptions frequently modify the landscape in small ways, places are understood to move' (1999: 44). Landscape is also shaped visibly through the movement of people. The whole of Sia Raga history, recent and 'deep', is characterised by a constant flux of people moving across the land. Physical evidence of abandoned village and ceremonial sites, in the form of old house foundations or the ancient mwele (cycad palms) that mark the location of ritual pig-killings, are discernible almost everywhere on the upper plateau of the North Pentecost landscape. Such evidence attests to a continuity with today's situation in which whole villages may sometimes take up roots, and set them down at new locations, often joining with or separating from larger villages.

In North Pentecost, physical space is transformed into meaningful place through continuing reformulations of locality — of house planting and replanting, crop planting and harvest. Through these processes, it becomes imbued with layers of memory that are etched into the landscape. Where individual and group identity is conceived as taken from the land and infused into it (Rodman 1985: 68), the ability of people to interpret the landscape thus becomes vitally important to the forging and strengthening of those identities. Knowledge of the memory of landscape - of houses built, gardens tended, or of ancestral connection ritually or otherwise affirmed - and an ability to retrace the tracks between known places help people to recognise their identity as a series of itinerant linkages. It is through such knowledge that people are able to legitimate their rights and ties to particular pieces of land.

In this chapter, I explore some central idioms by which the Sia Raga understand the relationship between people, place and landscape, particularly as these are articulated through the important concept of vanua. After briefly 
discussing the term vanua in relation to social practice, I do so initially through tracing the importance of North Pentecost founding ancestor Bwatmahanga. This is achieved through the presentation and analysis of a number of compelling images that were shown and explained to me by my North Pentecost father, mentor and ratahigi (in Bislama: Jif, or 'chief'), Ruben Todali. The arboreal nature of these 'land-tree' images provides insight into Sia Raga interpretations of landscape and habitation in terms of a dynamic historical emergence. Through such images, the relationship between people and place is conceptualised in terms of an itinerant cartography - stasis and growth built into the same image (compare with Patterson, this volume). In conclusion, the paper shows how the shape of this history is also made to incorporate important political issues within the neo-colonial present.

\section{Atatun Vanua: The People of the Place}

The term vanua intersects with numerous other Raga words in communicating ideas of location, space or place. In particular, vanua is closely related to the word tano, which may also be used in the identification or description of particular areas of land. In contrast with vanua, however, tano pertains more specifically to the physicality of the land, and in this way it can be used to mean 'ground' or 'soil', and appears in constructions such as tanoga (muddy) and taniadu (ashes). Tano also sometimes appears as a locative prefix - such as in tanon alhuhuni (west) and tanon ha oha o (handle). In this way, it overlaps with the more commonly used term, ute, such as in ute maragasi (hilly place) or ute gogona (restricted place). Unlike both of these terms, however, wherever the concept of vanua is used it always carries with it the profound sense of identity that the Sia Raga feel in relation to place and the importance of the experience of place as lived social space (for cognate Ambae terms, compare Allen 1969: 132, Rodman 1987: 35, Bolton 2003: 132; also Patterson, this volume).

Though vanua may also be used somewhat loosely to refer to any area of land, village or indeed to whole islands, in Raga it pertains more specifically to the hundreds of individually named pieces of land into which the whole region of North Pentecost is divided. Individual vanua are usually little more than an acre or two in size. Indeed, larger contemporary villages often span several vanua. These land segments provide a key category for the regulation of rights to utilise land as gardens (uma), household dwellings (imwa), or in any other capacity.

Although anyone may be granted rights to utilise the land within a particular vanua, these rights are usually maintained by the authority of individual descent groups. Just as the members of individual descent groups are somewhat dispersed across the Sia Raga population, each descent group retains custodianship of many individual vanua that are scattered throughout the North Pentecost landscape. Some vanua are, however, identified more specifically as bwatun 
vanua (literally 'source', 'foundation', 'head' or 'roots' of the vanua'). ${ }^{3}$ Bwatun vanua represent the specific origin places of individual descent groups, with which they share names, such as Anserehubwe, Gilau or Atabulu (see also Yoshioka 1988: 21). Each Bwatun vanua is characterised by the existence of a bwaru (ancestral grave site). These roughly circular stone piles contain the resting places of primordial and subsequent ancestors, the atatun vanua ('people of the place') from whom the people of Raga today descend. ${ }^{4}$ Atatun vanua, who are described as 'ghosts' or 'devils' in Bislama, continually inhabit the vanua of their death. 5

While many vanua do not contain any significant features, some are likewise distinguished by stones (vatu), cycad palms (mwele) or other significant historical markers that provide dovonana ('memorial' or 'proof') of the acts by which ancestors have in some way merged with the earth of that place, especially through the performance of pig sacrifice. Today, through the ritualised spilling of pigs blood and the subsequent appropriation of ancestrally defined 'pig names' (ihan boe), people continue to affect the absorption of essential ancestral qualities. Through this process, land, ancestors and people become merged. The ability to identify ancestral grave sites and other markers and to trace one's descent through the chronological recollection of those ancestors that they contain or represent is important in claiming rights to utilise land contained within individual vanua. Individuals are able to claim links to a great many vanua, and do so strategically.

\section{Bwatmahanga: The Foundation Diverges}

According to Sia Raga histories, the division of the land into vanua and bwatun vanua occurred as part of the same purposeful process and along the same tracks by which North Pentecost was colonised by their ancestors. This all began with Bwatmahanga, the 'first man' of Pentecost. According to Jif Ruben Todali, the appearance of Bwatmahanga defines the beginning of the third epoch or 'generation' (tauva) of Sia Raga cosmogony. ${ }^{6}$ He was not the first sentient being to inhabit Pentecost, but he was the first person (atatu) to take fully human form, and, along with his siblings, was the apical ancestor of the people of Raga today. He is also remembered as the first 'chief' (ratahigi), the creator of the first household dwellings (imwa) and 'men's houses' (gamali), and pioneer of the road to abanoi. Abanoi, an invisible other world (or 'paradise', as it is referred to in Bislama), is woven through the material world of human experience (ureure), and is inhabited by ancestors (atatun vanua) and other spirit beings such as tavalurau, whose name-meaning literally, 'the other side of the leaf' - evocatively describes the relationship between the two realms. ${ }^{7}$ Turning a leaf ( $\mathrm{rau}$ ) over merely renders the other side invisible. While both sides are always 'present' to consciousness, only one is accessible to the eye. As Jif Ruben Todali explained abanoi to me: 'You can't see it, but it is here with us anyway.' 
Atmate, the 'spirits' or 'souls' of the dead, are also sometimes described by the related term tavaltena, or 'spirits of the other side'. Through these terms, the relationship between the two cosmological 'sides' of ureure and abanoi is pictured as simultaneously joined and separated. Bwatmahanga is the historical embodiment of key architectonic concepts. Two of the most important of these are present in his name: bwat, meaning 'source' or 'foundation' (see above), and mahanga, to 'branch' or 'diverge'. Bwatmahanga is the figure of the one that becomes two.

Bwatmahanga appears in many origin narratives throughout the northern islands of the archipelago, and wherever he does he is always accompanied and thwarted by his adversary, Tagaro. ${ }^{8}$ In North Pentecost, part of the reason why narratives involving Bwatmahanga and Tagaro are so important is that they engage with the origin of human engagement with otherness. They thereby provide insight into the ambivalent dualism that has become the fundamental architectonic feature of the Sia Raga cosmological, metaphysical and social universe. As Battaglia (1990) found of the Sabbarl, the idea of dualism in Sia Raga ontology is not simply positive and productive, but has equally negative and destructive tendencies. In this way, the entangled careers of Bwatmahanga and Tagaro suggest a relationship fraught with productive potential and antagonism. Like the monster Katutubwai of Sabbarl children's stories, Tagaro's relationship to Bwatmahanga represents that of 'the spectre of the ambivalently valued Other that haunts the texts of human life - texts taken as interactional or 'dialogical' constructs, where the Other is historically an aspect of one's own life' (Battaglia 1990: 38). For Sia Raga, the processes of birth, growth, procreation, death and knowledge all depend on the continuing activation and engagement of that otherness, which contains the power to give and to take away. ${ }^{9}$

Tagaro's arrival marks the beginning of human violence and of an era in which peace (tamata) no longer constitutes the natural order of things, but must be constantly strived for and negotiated. Today, the search for tamata represents the ultimate stated goal of all Sia Raga ritual enterprise. In the course of striving for social and cosmological unity within their already divided world, division itself becomes a part of that strategy. Jif Ruben once explained to me that marriage (lagiana), funerals (mateana) and male rank-taking ceremonies (bolololi) all ultimately represent strategies or roads (hala) to the attainment of that same goal: peace (tamata). In all cases, these strategies involve the engagement of dynamic relationships struck between things divided, or 'sides' (tavalu), found for instance in the distinction between the two moieties (themselves called tavalu), the lived world (ureure) and the Other world (abanoi), and more recently between alengan vanua (local fashion) and alengan tuturani (the fashion of whites). As I hope will become more apparent throughout the course of this paper, tamata lies at the ideological centre of moiety division, the associated division of people and land into individual descent groups and vanua, as well as the networks of 
exchange by which these are bound together. As almost anyone from North Pentecost will tell you, peace is the true goal of all Sia Raga cultural endeavour.

\section{Bwatuna: Foundations for the Land-tree}

Figure 1 is a diagram that was drawn by Jif Ruben on a blackboard in the Avatvotu village gamali, and which I copied into my field notes in June 1999, a month after my arrival there. It is headed with the words, 'Vanua toto deti-bwatun touva' ('Here is a tree of place - foundation of generations'). ${ }^{10}$

Figure 1: Land-tree one

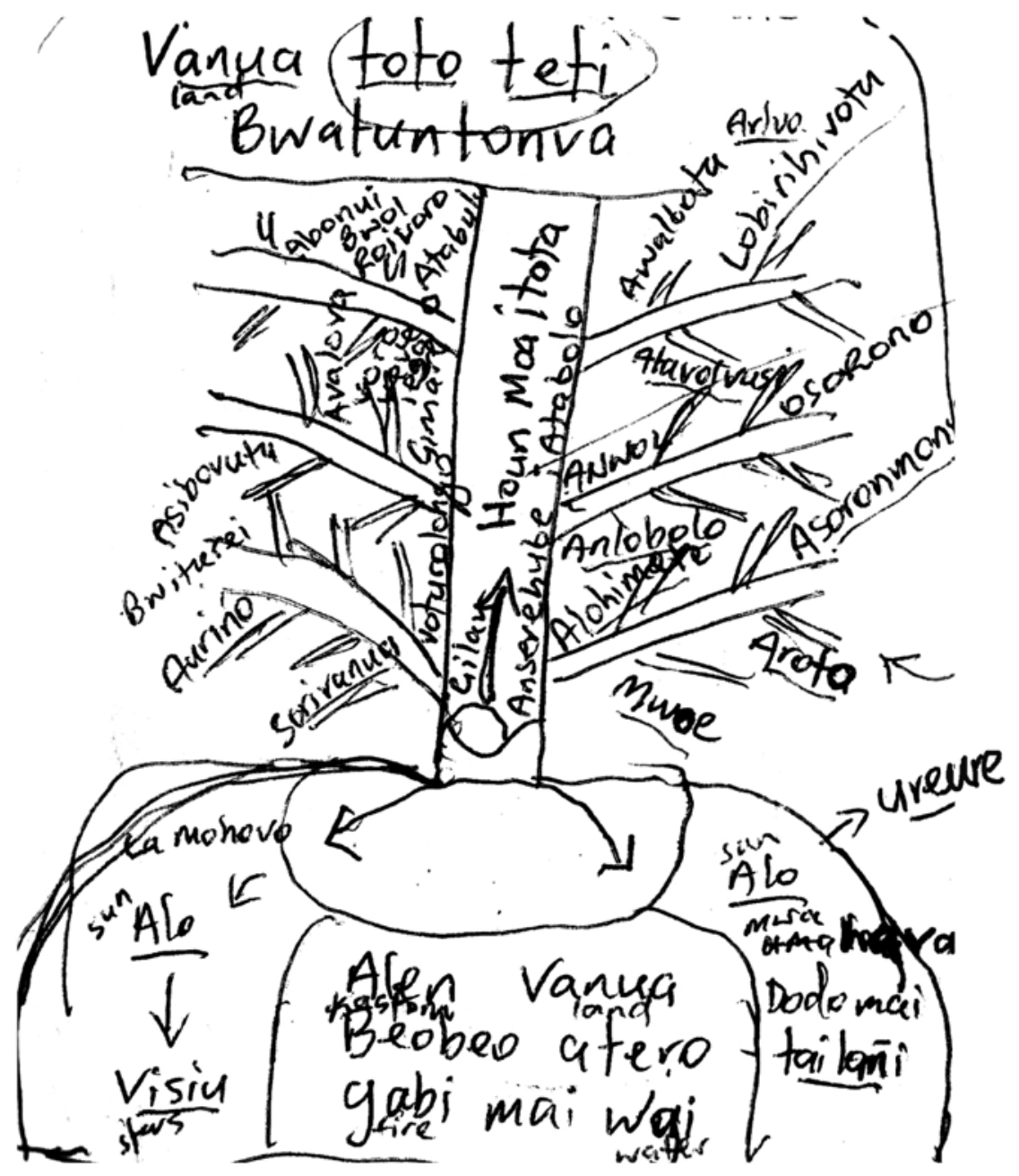


Blending cosmography with social topography, the image shows the emergence and presence of the differentiated cosmos that I have begun to trace above. It depicts the physical emergence of the island of Pentecost, and at the same time it traces the past and present distribution of atatun vanua, the 'people of the place', across that landscape. The island is imagined as a tree (toto), its branches ramifying on either side of a stout trunk. The tree grows from the soil of a unitary plenum, of land (vanua) and surrounding cosmos (ureure). This land is described as having formed during a cosmogonical episode in which fire and water met, reacted and affected the emergence of solid rock from the sea. Jif Ruben uses the words 'Alen Vanua beobeo atero gabi mai wai' ('kastom land pushed from beneath by fire and water'). ${ }^{11}$ The land is enveloped by the stuff of ureure, the 'material' cosmos of lived experience - including 'alo, mahava, visui, dodo mai tailangi' ('sun, air, stars, rain clouds and white clouds') - of which the land (vanua) is also a part.

Historical provenance for this remarkable land-tree image is the divisive turbulence of the early 20th century, its recent emergence being framed within the struggle for hegemony and the power to dictate cosmology by recent converts to the Anglican faith and those supporting kastom. Jif Ruben describes the 'inventor' of this technology - his father by birth, Vira Livlivu — as a man of questions, a man who needed to understand (iloi) everything. For this reason, while his attitude towards the growth of Anglicanism was essentially ambivalent, he was at the same time drawn to its novel spiritual ideas and to the new forms of knowledge that it was importing, and which were becoming increasingly popular throughout the region. As a result of his thirst for knowledge and his desire to further explore the ideas and teachings of the Anglicans, Vira Livlivu became a catechist, and thereby learned to read and write. In the evocative and ambivalent image with which Jif Ruben enjoys describing him, Vira Livlivu stands at the door of the local village church house, with one hand he rings the bell for Sunday service, in the other he holds a rifle.

As this image suggests, Vira Livlivu came to the conclusion that the knowledge and practices contained within church and kastom should be mutually maintained in Sia Raga society. He saw that those two apparently competing ideologies might be incorporated into a productive duality as new figures within the social and ontological framework of tavalui ('sides'). However fraught, this is a common sentiment today. In the context of the early 20th century, though, his position would no doubt have been quite novel, especially in consideration of the levels of conflict and violence that characterised the division (see Taylor 2003). 
As a consequence of his interests, and in the hope that a fusing together of church and kastom might lead, ultimately, to tamata (peace), Vira Livlivu encouraged each of his two sons to pursue one of these divergent paths of knowledge. Today, Jif Ruben is the recognised kastom leader of Gelau, while his brother, Peter, was for many years catechist to the area. ${ }^{12}$ On Sunday mornings, during my major field trip, Peter would read the Gospels to a smattering of local parishioners at the Lagaronboga church house. This was the time during which Jif Ruben, ten minutes walk up the hill, would habitually work with his exercise books, recording his knowledge of kastom. Utopian visions of tamata (peace) also provided the underlying reason why Vira Livlivu devised his 'land-trees' and passed them onto his son, Jif Ruben. Considering the continued importance of the knowledge that they systematise Jif Ruben has passed them to his own son, Kolombas.

Shortly after I arrived at Avatvotu - and before I encountered the land-tree on the blackboard - Jif Ruben spent one long afternoon picturing for me the shape and trajectory of Sia Raga cosmography. He began by describing to me the island's first creation as rock and its emergence from the sea. He went on to explain to me the processes of death and decay by which soil was formed from the moss (lumute) that settled on the rocks of the newly formed island, and of how that soil provided a substance in which a process of rebirth could occur, thus enabling that moss to diversify, eventually becoming the many plant and animal life forms that exist today. 'Lumute,' he told me, 'is the basis of all life.'

Jif Ruben always provided caveats to these renditions, interspersing his narrations with statements such as this: 'I don't know if what I'm telling you is true or not. This is just what the old men from before believed. It may be true. I don't know.' Yet he would also contradict his modesties by pointing out that this vevhurina (history, or more literally, 'talk because of it') could nevertheless be authenticated beyond all others. Proof that humans are ultimately derived from lumute, through a process of incremental transformation, is retained in the physical characteristics of the first animal to appear on Raga, the bebeure. As Jif Ruben told me, if you tie one of these moths to a piece of string and ask it a question, such as 'Where is the rough sea?' or 'Which way is north?', it will attempt to fly off in that direction. 'It knows,' he said. 'That small piece of knowledge, that people emerged from it [the moth], is still here [retained in the moth]. This is apparent in that the knowledge that we have, this small knowledge, is shared by the small bebeure' (recorded at Avatvotu village, May 2000). Just as the existence of graves, cycads and rocks authenticate people's relation to place, so too the bebeure contains the dovongana (memorial, proof) of Jif Ruben's account of Sia Raga history, and, by extension, of the authority of the land-tree. 
On a more pragmatic level, the land-tree operates as a central technological device whereby Jif Ruben is able to maintain his position as judicial negotiator at land-dispute meetings, which, given the considerable flexibility of the Sia Raga land-tenure system, are commonplace. Insofar as social identities in the present are seen to be crucially linked to the landscape through the foundational actions of ancestors, the land-tree is therefore made to function in a very practical and disciplinary way: to help settle land disputes by demonstrating the historical relationship between the land and its embodiment by the ancestors of disputants, and therefore by the disputants themselves.

During the time in which I lived with him, Jif Ruben was often called away to different areas of North Pentecost to help settle land disputes. He did not, however, display or refer to these images in such meetings. This does not mean that they constitute some sort of 'secret knowledge'. Rather, Jif Ruben was conscious that reference to written texts in such contexts is often viewed by others as undermining the authority of a speaker's arts of memory and of oration. Instead, in actual practice, the land-tree provides one of many mnemonic strategies by which named plots of land (vanua) are known and ordered-also apparent in house architecture and weaving patterns, for instance. It is usually referred to or rehearsed in private, on paper or the blackboard in the gamali. To my knowledge, only a handful of adult males draw them, and all of these are residents of Gilau.

\section{Halana: The Ways of the Land-Tree}

The tree is already the image of the world, or the root the image of the world tree. (Deleuze and Guattari 1987: 5)

The primary function of the land-tree is to provide a map of relations between landholdings based on the history and colonisation of that land by ancestors. This is made more obvious in Figure 2, where the 'tree' is clearly the prime object of attention, and the more general cosmological elements are simply represented alongside the image of a globe, identified as such by the inclusion of lines of longitude and latitude. ${ }^{13}$ As Jif Ruben explained it to me, the words that appear alongside the various branches and sub-branches of all of these land-tree images are the names of ancestral bwatun vanua, or the 'foundation places' of descent groups (see above). The collection of names is representative rather than exhaustive, and this mainly explains the significant differences between the two examples shown here. Some of the bwatun vanua appearing on these images are the names of contemporary hamlets, such as Asaola, Arevo, Atabulu and Amangao in Figure 1. Other names are said to represent the sites of hamlets long since abandoned. 


\section{Figure 2: Land-tree two}

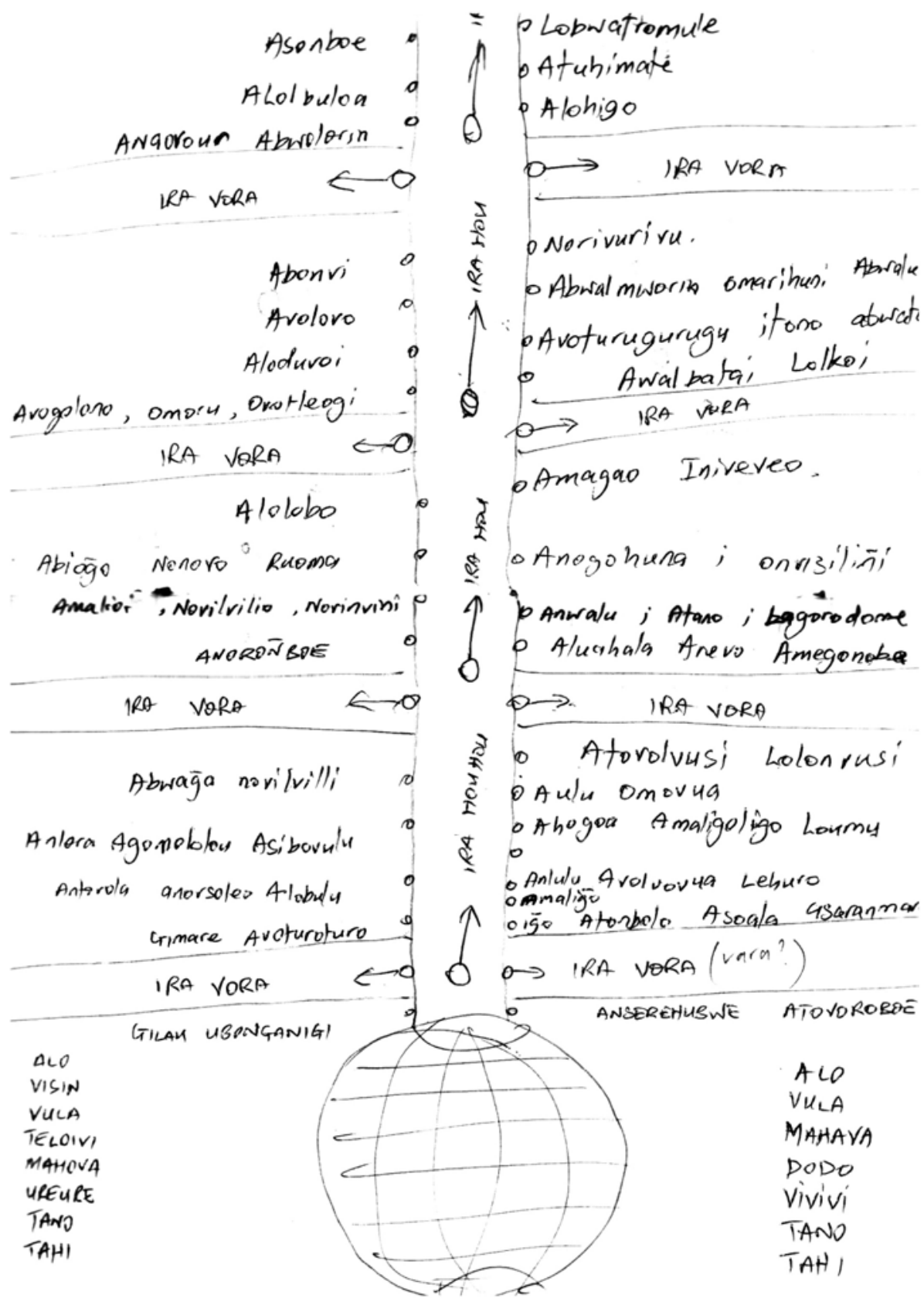

The land-tree very clearly demonstrates the centrality of itinerant principles, and especially of series and divergence, in Sia Raga interpretations of social topography. The analysis of these can readily be linked to recent appraisals in 
Pacific anthropology of Deleuze and Guattari's distinction between rhizomic and arborescent models. ${ }^{14}$ In apparent contradiction to Deleuze and Guattari's suggestion that Oceania, 'in particular', offers 'something like a rhizomic model opposed in every respect to the Western model of the tree' (1987: 18), their shape is clearly tree-like. Thus in Deleuze and Guattari's terms, and like the figure Bwatmahanga (discussed above), they may be seen to incorporate a certain 'tree logic' of 'tracing and reproduction'; something akin to an endless development of 'the law of the One that becomes two, then the two that becomes four' (Deleuze and Guattari 1987: 5).

Alan Rumsey (2001) has tested the application of Deleuze and Guattari's models of rhizome and tree to a variety of indigenous forms of 'topographic inscription', such as they are described in anthropological accounts from Australia and Melanesia. His discussion juxtaposes what he sees as the essentially 'rhizomic' nature of Aboriginal dreaming cartographies with several more ambiguously 'arborescent' examples from Melanesia. (The Moorhead River and Iatmul regions of PNG, and the island of Tanna in Southern Vanuatu, provide his main examples from Melanesia.) In the terms of this discussion, Rumsey notes the appearance of striking similarities across Melanesian cultures

in the way the earth is interpreted as a surface of inscription, in the dense interconnectedness of named places along tracks established by the movements of protean creator figures, in the localisation of knowledge about these movements and the role that that knowledge plays in the reproduction and contestation of present-day people's rights to land. (Rumsey 2001: 32)

Rumsey's description of arboreal metaphor in the Moorhead River region of PNG, which draws mainly on the ethnographic work of Ayres (1983), is in many ways cogent to the form and movement of the images discussed here. For the Moorhead people and the Sia Raga, the tree seems to be the main figure by which people understand the spatiality of social relationships and the mapping of these onto the landscape. Indeed, this has also been noted as a common theme across the Austronesian language area (Fox and Sather 1996). Furthermore, in both cases the image of the tree as a fully formed object is not as important as an attendance to the nature and trajectories of its growth (Rumsey 2001:28). This final section is concerned with discussing the tree as just such an image, as a network of hala (ways, roads) by which the Sia Raga form an understanding of relationships to place, and also to each other, across space and time.

As is the case in Rumsey's (2001) discussion of Moorhead interpretations, the Sia Raga identify two places of original separation and dispersal for the formation of the cosmos and the island itself, and the peopling of the land. The first of these is the home of Mugarimanga, whose name, somewhat like that of Bwatmahanga (above), suggests the opening of 'sides', here being the two valves 
of a cockle shell-mu (mother), gari (cockle shell), manga (to open). Mugarimahanga's first-and second-born sons accidentally opened a hole in the ground from which issued a great flood of salt water, thus creating the sea that now divides Pentecost and Maewo, two islands that were previously joined. ${ }^{15}$ Fleeing from the flood, Mugarimahanga's 12 children dispersed and embodied the natural environment, becoming the rain, wind, waves, tides and stones. 16 Some time after the embodiment of ureure (the cosmos) by these primordial atatun vanua, two of Mugarimanga's children met one day in the middle of the island of Pentecost at a place in the bush, somewhere above where the village of Bwatnapne is located today. ${ }^{17}$ These were a woman called Mumate, who had become the 'quiet' western sea, and a man called Mauri, who had become the rough sea of the east. Without realising that they were in fact brother and sister, Mumate and Mauri met once again at Atabulu where they married and had children. ${ }^{18}$ The first of these children, and therefore the 'first man' of Pentecost itself, was Bwatmahanga (the 'foundation diverges'), primogenitor of the Sia Raga today.

The second location is the home and place of death of Bwatmahanga. This is the starting point of human dispersal, but also of return, and it is with this location that Jif Ruben's land-tree image is primarily concerned. Anserehubwe is located at the extreme northern tip of Pentecost Island. Following Sia Raga directional orientation, in which to travel southwards is to go 'up' (hae), this point represents the very base of the island. It is thus located in the district called Ahivo ('at down'). The Sia Raga identify Anserehubwe as the pre-eminent bwatun vanua (foundation place), the unique place of origin and departure for the human settlement of Pentecost. It is also a place of merging (hubwe), for it is through this place that people at death 'return' to abanoi (the Other world) and become fully merged as atatun vanua (people of the place).

From Anserehubwe, the dispersal of the Sia Raga population across the land is reckoned to have followed specific patterned trajectories. As Jif Ruben's representations elegantly show, the image of the tree provides a binding metaphor by which this dispersal is traced, and eventually becomes a kind of cartography. Thus space and time are condensed within the same image. Attention to the manner in which the dispersal of people across the landscape is considered to have 'taken place' - the growth of the tree - is made clear by the presence of circles and arrows in the second of the figures presented. As Jif Ruben explained it to me, circles represent bwatuna (foundations, roots, places of settlement) and arrows represent hala (ways, roads, trajectories).

As Jif Ruben further explained, the land-tree demonstrates that dispersal took place in a series of departures divided into two successive phases. Each phase is characterised by a distinct pattern of movement, the first being a progression of what Rumsey describes as 'lineal segmentation from a unity' (see 
Figure 3 [left], adapted from Rumsey 2001: 29), the second a mode of bifurcation from the points already established along that lineal segmentation (Figure 3 [right]). While obviously recognisable as a kind of 'branching', the latter kind of movement is clearly not identical to another mode described by Rumsey; rather than appearing as a somewhat rhizomic 'scattering or fragmentation from a starting point or centre' (Rumsey 2001: 29), what occurs here is serial bifurcation at specific nodal points (bwatuna) that are distributed evenly along a central 'trunk'. This pattern may be further imagined as recurring on subsequent branchings, and may be realised ultimately as an infinitely reticulating fractal (images not presented here, see Taylor 2003). The image of the tree is the image of the island, and it is also the image of the leaf.

Figure 3: Lineal segmentation from a unity (left, after Rumsey 2001: 29), and serial bifurcation at specific nodal points (right)
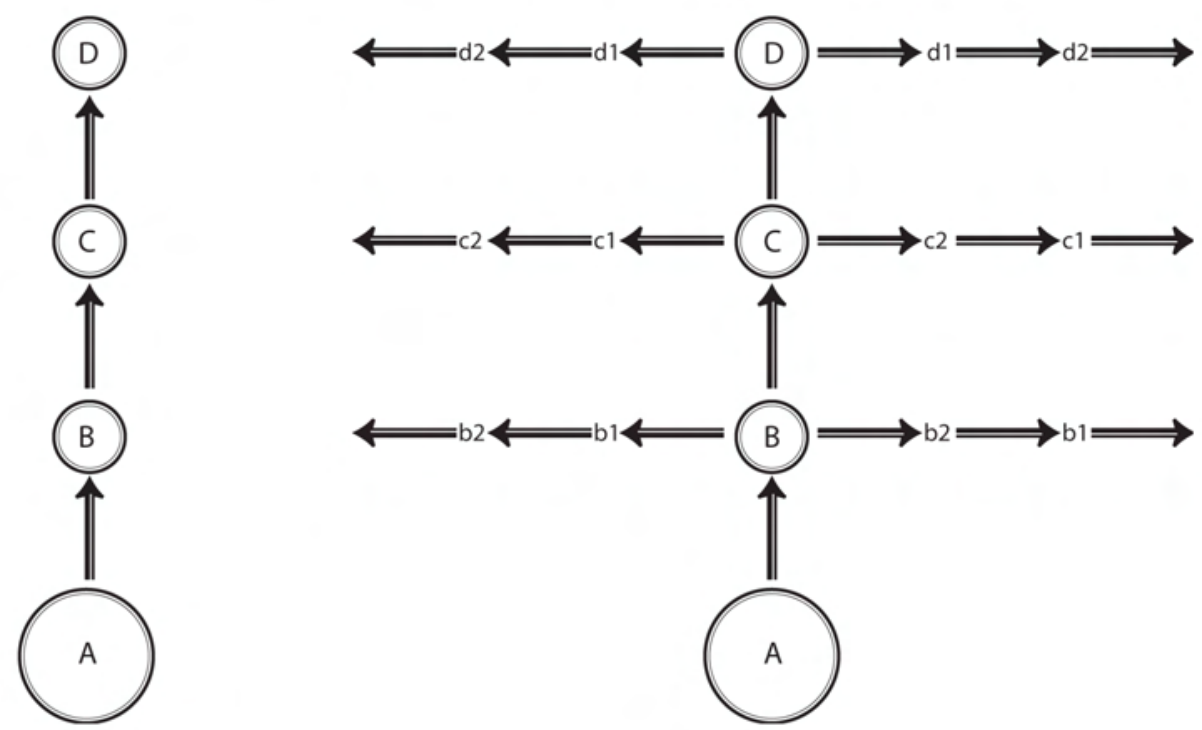

In explanation of these different itinerant modes, Jif Ruben told me that when the original departure from Anserehubwe occurred, the rules of marriage - the division of society into two exogenous moieties - had not yet been devised. Being devoid of the lateral dimension of 'sides' (tavalui), lineal movement was the only available option. While some people stayed at Anserehubwe a group of people moved upwards - or, in Western geographical idiom, southwards - to settle on a new point on the land. At a later stage, a division from this second group departed once again, continuing along the same trajectory, up the 'trunk' (bwatun gai) of the island. As this pattern of lineal segmentation continued, the children of those groups left behind formed their own new bwatun vanua (foundation places) at the places where they settled. 
As Jif Ruben further explained to me, the main impetus for the succession of departures was fighting over land. Social tension was fuelled by the restrictive, linear nature of their pattern of movement and settlement. Nevertheless, throughout the course of their journeying, the people had been developing their knowledge. By the time they began to reach the 'end of the line', they came to a point where they were able to strategise new roads ( hala) for the maintenance of peace (tamata). These roads, being the related rules of marriage and land tenure, were based on the designation of two moieties. These are known today as Bule and Tabi. With the division of the population into two tavalui (sides, halves, partners), successive generations began to move outwards rather than upwards, thus forming branches (raran gai) on either side of those previously established nodal settlements. With women moving across from one tavalui to the other in marriage, yet with land being retained within the matriline, the fair and equal distribution of land was ensured.

\section{Tavalui: The Divided World}

When Codrington first noted the pervasiveness of the idea of 'sides' as a socio-linguistic category linking the islands of northern Vanuatu, he argued that the extreme cultural and linguistic diversity that he found to be characteristic of the region must have emerged from a more unified source. ${ }^{19}$ Thus he wrote of the Banks Islands:

The identity of the language is conspicuous, however mutually unintelligible the dialects may be; and wherever a native of one of these islands may land he may find his due place in the gamal, the clubhouse of the Suqe. What is chiefly remarkable as showing how comparatively modern are these diversities, even of language, is the identity in all these Northern New Hebrides of the division of the population into two 'sides of the house,' which obtains in the Banks Islands. (Codrington 1881: 291; see also Wilson 1932: 65)

The notion of duality is also a pervasive feature of the Sia Raga conceptual universe in which it is considered that all things should have two 'sides' (tavalu), and that everything must have a 'partner' (also tavalu). ${ }^{20}$ While in some instances such duality is considered in terms of hierarchical opposition - a person's strong, 'good' right side is distinguished from their left side, which is weak and 'bad' - it is more often the case that the two are seen to form an ambivalent yet productive complementarity. ${ }^{21}$

The division of the entire population into two exogamous matrilineal moieties, Bule and Tabi, provides the most powerful example of how dualism works as a productive organising principle within Sia Raga society. The two moieties are commonly referred to as tavalu, which has the basic meaning of 'opposite', 'side', 'half' or 'partner'. ${ }^{22}$ An individual's sense of belonging to either one of the two 
major social divisions - of being either Bule or Tabi - is inscribed from birth as one of the most basic elements of social identity. Inclusion in either of the two moieties provides the basis of one's social categorisation, and for this reason strangers who arrive to stay in the area for only a few days are quickly defined accordingly. Conversely, to suggest that someone belongs to neither tavalui is considered the most serious of insults. One turn of phrase for such an accusation, matan gai halhala, is translated by Hardacre as 'son of a floating stick' (Hardacre n.d.: 40). This reflects the arboreal 'land-tree' images of kinship and social organisation described above. It also clearly resonates with Jolly's discussion of the privileging of different kinds of movement amongst the Sa speakers of South Pentecost. In North Pentecost, also, whereas rootedness and motivated movement are highly regarded, 'mere wandering or floating is deplored' (Jolly 1999: 284).

One of the many important characteristics of the distinction between one's own moiety members and those of the 'other' lies in the way it permeates the ceremonial and ritual duties that punctuate Sia Raga life. At such occasions, through performing those duties and obligations that are so important in the creation of the social identity of people, matrikin and patrikin 'become' interminably embroiled within a process of reckoning, delivering and receiving.

Like the role of hands in the making of string figures, tavalui construct the division across which meaningful hala (ways, roads, trajectories) can become linked. Indeed, tension and interplay between the moieties is considered to be essential to the maintenance of efficient and harmonious social relations and production. A strict rule dictating that a person may not marry a person of his or her own moiety is maintained, while major prestations in large part follow a cross-moiety trajectory. Intra-moiety marriages, called bona, are said to sometimes occur despite ridicule and ostracism. Such unions are, however, very rare, and only one was evident during my visit.

As Wagner found among the Barok people of New Ireland, the moieties contain their own and nurture the other, and thereby 'stand in a relation of asymmetrically and perpetually unresolved hierarchy to one another' (Wagner 1986: 49). In this way, Layard noted a 'creative tension between the moieties, which are at one and the same time necessarily opposed to one another and also essential to one another's existence' (Layard 1942:103). Whether performing transactions with the other world, abanoi, or in prestations between kin, all ritual action is concerned ultimately with the redefinition of differentiation and the relationship between tavalui (sides). The relationship between sides therefore appears as a separation and a binding together. Between them the Sia Raga, anxiously negotiate strategies by which to sustain a perilous equilibrium; to stop the sides from falling away from each other, but also from merging into confusion. 
In North Pentecost, as the result of this creative tension, the two social divisions are perceived as entangled, or 'stuck' to one another. This 'entanglement' (cf. Thomas 1991) is described by the word wasi. Being wasi is itself considered a two-sided predicament, with good and bad qualities. It implies difficulty and costliness, but perhaps more importantly, strength, tenacity and security. For this reason, Sia Raga social life is considered to be inescapable, a situation that may give rise to feelings of resentment as well as assurance. In particular, like a severe case of 'tall poppy syndrome', the tension of otherness is seen to act in such a way as to negate assertions of individual difference. People complain that it is hard to get ahead, that they are constantly swallowed up by society. As one person told me, to be man Raga is like being trapped in the jaws of a clam shell. ${ }^{23}$

\section{Alengan Tuturani: The Ways of Foreigners}

Appearing in contradistinction to this appraisal of Sia Raga social organisation are widely held impressions of alengan tuturani, or the 'ways of whites/foreigners'. Tuturani has become an important oppositional category in the Sia Raga classification of their world, providing terminology for marking the otherness of introduced objects and styles. The concept of tuturani gives the Sia Raga a tag for most every plant, animal, artefact and kastom that has crossed their shores since contact with Europeans (cf. Dening 1980). People might speak of ginau tuturani (white man's things), including such things as uhi tuturani (fruit: tuturani, pawpaw) and wai tuturani (water: tuturani, alcohol). In this way, alengan tuturani (white man's fashion) is contrasted with alengan vanua (ways of the place) as two related but opposing 'sides' (tavalui) within Sia Raga classificatory idiom.

Once I told Jif Ruben that my parents were divorced, and that this was not an uncommon situation for children of my generation. In response, he suggested that together we write a book outlining the basic principles of Sia Raga kinship, and of moiety dualism in particular, and that we present this book to the New Zealand Government. The nationwide implementation of this social strategy in New Zealand would, he believed, put an end to the break-up of marriages.

When people say that there is no divorce on Pentecost they are articulating their faith in alengan vanua (ways of the place), and of a social cohesion bound up in the play between 'sides' (tavalui). ${ }^{24}$ At the same time, Jif Ruben's proposal reflects the idea that, in contrast with Sia Raga sociality, the world of tuturani (whites) is 'free'. It is a society without structure, and devoid of the restraints formed by the webs of connectedness that bind the two moieties together. The price of this freedom, social chaos, is seen to extend beyond the family sphere. It is also made evident in negative images of theft, violence, self-advancement, and the gap between rich and poor in the West. 
What follows is abstracted from a North Pentecost creation history that was narrated orally by the late Father Walter Hadye Lini in 1981. This history, which was transcribed and translated from Raga by Lini and David Walsh, is titled 'Veveven bwatun tauvwa, ata la Vanua Raga', or 'A story about the beginning of creation, from Pentecost Island' (Walsh 1981). ${ }^{25}$ After the emergence of the island from the sea, the story begins with the birth of a baby boy from a kind of shellfish. After the boy grows up, he meets a sea snake that later transforms into a woman:

Thus the man and the woman came together and produced children. They two produced ten children while they stayed there, at Atano. They produced ten children, and they [the children] stayed there-and then they two moved on and went so that they would stay at the place of that woman. They both went and stayed there, at Anarasi. They stayed there until they produced some children there. Their children were many - they two arose from there and went up and stayed at Loltongo. They stayed at Loltongo and they produced some children there. They produced some children, and they [the children] stayed there-they two arose from there and went up and stayed at Bwatnapni. They stayed there and produced some children there also. They produced some children and they [the children] stayed there, and then they two arose from there and went up and stayed at Vat-tangele. They stayed at Vat-tangele and they produced children there also.

It - all the children that they two produced - began at Ahivo and went up until it reached Vat-tangele; some were white people and some were black people. Today we call the white people tuturani and the black people atatmato. (Walsh 1981: 368-9)

The people then began quarrelling with a land snake, teltele, who eventually trapped them in their village by covering the entrance with a large rock. They then decided that the white people should try to escape by digging their way out of the village:

The tuturani dug a hole - it went down underneath the fence of that village. They dug it - it went until it went down and came out on the coast; but on that coast stood various boats they had made - canoes and sailing ships. When the tuturani went down so that they would get away, they took those sailing ships and went with them, and those black people stayed and kept the canoes that lay there.

The tuturani went - they went and stayed at other islands on which today tuturani are found; and the black people stayed at Raga - so today black people are found on Raga island ... Raga people today say that the tuturani went with those sailing ships and also with all the knowledge 
and wisdom, and therefore today the black people stay back from certain knowledge and wisdom which the tuturani know today. (Walsh 1981: 370; all spelling is as it appears in the original text.)

This history differs from those that I was told on North Pentecost in several important respects. The unitary origins and kinship of atatmato and tuturani, along with the latter's departure from rather than arrival at Pentecost Island, represents a revision that bears relation to the political climate of national independence in which the story was told. ${ }^{26}$ However, the narrative components provide a condensation of themes that recur frequently in Sia Raga histories. ${ }^{27}$

In particular, 'upward' (hae) colonisation of the land along a north to south itinerary followed by division or branching into 'sides' reinscribes the crucial orienting pathways by which the Sia Raga understand the emergent and present relationship of people to knowledge and place. Here, moving from the village of Atano in the far north (at Ahivo, 'at down'), then moving progressively southwards through a series of places-Anarasi (at Abwatuntora), Loltong, Bwatnapni (in Central Pentecost) - until eventually reaching Vatun Gele at the very south of the island, the peopling of the land occurs along a reverse trajectory to that which was forged by Bwatmahanga in his journey to abanoi. Significantly, histories recounting the 19th-century arrival of the Anglican Church and its spread across the island also follow this path (for instance, Leona n.d.). Likewise, the departure of tuturani, 'with those sailing ships and also with all the knowledge and wisdom' (Walsh 1981: 370), represents a splitting into ambivalently composed 'sides'. This is understood to exist within much the same kind of relationship as the two Sia Raga moieties, Bule and Tabi.

In this chapter, we have seen how the people of North Pentecost deploy metaphors based on arboreal imagery in order to explain ideas of origin, ancestry, historical emergence and social organisation. In the apical ancestor, Bwatmahanga, we saw how the concept of foundations or roots (bwatuna), coupled with that of bifurcation or branching (mahanga), constituted significant features of reference within these metaphors. The importance of trees as images of spatio-temporality rests not only in their shape, but in the manner of their growth. The becoming of the tree is seen to 'take place' along these two interrelated trajectories ( $h a l a$ ), one appearing to take the form of lineal sequence, the second the form of divergence or branching. As the land-tree designs drawn by Jif Ruben and others demonstrate, the tree has the capacity to incorporate simultaneously an atemporal cartography or topography and a spatialised temporality and itinerant history.

Anyone familiar with the ethnography of Southern Asia and the Pacific will be aware that the employment of trees as metaphors for understanding social topography on historical terms are common throughout this region. ${ }^{28}$ What is unusual about the Sia Raga example, and similar to the Moorhead people (Rumsey 
2001: 28), is that although this topography is considered to have emerged in sequential fashion, it is not perceived to be hierarchically ordered, as so often appears to be the case elsewhere. The Sia Raga conceive of historical linearity as articulated with spatial divergence, and in terms of this articulation the past does not appear as a series of substitutions, but rather as layers of renewal. Histories produced within the rubric of this ontology entail a condensation of the language of time into that of space and place. In stressing the presence of historical location and movement, the past is not seen to be wholly 'gone'. Instead, the past might constitute a crucial path of action. For people in ureure, travelling such a path entails an overcoming of crises brought about through the passing of time. This pathway leads to the perfection of abanoi, where lies the truth of the people of the place.

\section{References}

Allen, M. 1969. 'Report on Aoba.' Edited by Caroline Leancy. Incidental Papers on Nduindui District, Aoba Island, New Hebrides, written for the British Residency in the New Hebrides, Port Vila.

Allen, M. 2000. Ritual, Power and Gender. Manohar: Sydney Studies in Society and Culture.

Allen, M. ed. 1981. Vanuatu: politics, economics and ritual in island Melanesia. Australia: Academic Press Australia.

Ayres, Mary 1983. 'This Side, That Side: Locality and Exogamous Group Definition in the Moorhead Area, Southwestern Papua.' PhD dissertation, Department of Anthropology. University of Chicago, Chicago.

Battaglia, D. 1990. On the Bones of the Serpent: Person, Memory and Morality in Sabarl Island Society. Chicago and London: University of Chicago Press.

Bolton, L. 1999. 'Women, Place and Practice in Vanuatu: a View from Ambae.' Oceania, 70. pp. 43-55.

Bolton, Lissant. 2003. Unfolding the Moon: enacting women's kastom in Vanuatu. Honolulu: University of Hawai'i Press.

Bonnemaisson, J. 1994. The Tree and the Canoe: History and Ethnography of Tanna. Honolulu: University of Hawai'i Press.

Codrington, R.H. 1881. 'Religious Beliefs and Practices in Melanesia.' Journal of the Royal Anthropological Institute, 10. pp. 261-316.

Codrington, R.H. 1891. The Melanesians: Studies in their anthropology and folklore. Oxford: Clarendon Press.

Crowe, P. 1990. 'Dancing Backwards?' World of Music, 32. pp.84-98.

Deleuze, G. and F. Guattari. 1987. A Thousand Plateaus: Capitalism and Schizophrenia. London and New York: Continuum. 
Dening, Greg. 1980. Islands and Beaches: discourse on a silent land: Marquesas 1774-1880. Chicago: The Dorsey Press.

Fox, James J. and Clifford Sather. 1996. Origins, Ancestry and Alliance: Explorations in Austronesian Ethnography. Canberra: The Australian National University.

Goldman, L.R. and C. Ballard (eds). 1998. Fluid Ontologies: myth, ritual and philosophy in the highlands of Papua New Guinea. Westport (Conn.): Bergin and Garvey.

Hardacre, M. n.d. [c. 1910]. 'Raga Vocabulary.' Unpublished Manuscript.

Jolly, M. 1994. Women of the Place: Kastom, colonialism and gender in Vanuatu. Chur: Harwood Academic Press.

Jolly, M. 1999. 'Another Time, Another Place.' Oceania, 69. pp. 282-99.

Layard, J. 1942. Stone Men of Malekula: The small island of Vao. London: Chatto and Windus.

Leona, Richard. n.d. 'Uloilua mwa dau bwativuna Raga.' Unpublished Manuscript.

Morgan, L.H. 1964 [1877]. Ancient Society. Edited with an introduction by L.A. White. Cambridge: Harvard University Press.

Patterson, M. 1976. Kinship, Marriage and Ritual in North Ambrym. Sydney: Department of Anthropology, University of Sydney.

Patterson, Mary. 2002. 'Moving Histories: an analysis of the dynamics of place in North Ambrym, Vanuatu.' The Australian Journal of Anthropology, 13 (2). pp. 200-218.

Rival, Laura (ed.) 1998. The Social Life of Trees: anthropological perspectives on tree symbolism. Oxford and New York: Berg.

Rivers, W.H.R. 1914. The History of Melanesian Society. Cambridge: Cambridge University Press.

Rodman, M.C. 1985. 'Moving houses: residential mobility and the mobility of residences in Longana, Vanuatu.' American Anthropologist, 87. pp. 5672 .

Rodman, M.C. 1987. Masters of Tradition: Consequences of Customary Land Tenure in Longana, Vanuatu. Vancouver: University of British Columbia Press.

Rumsey, A. 2001. 'Tracks, Traces, and Links to Land in Aboriginal Australia, New Guinea, and Beyond.' In A. Rumsey and J. Weiner (eds), Emplaced Myth: Space, Narrative, and Knowledge in Aboriginal Australia and Papua New Guinea, Honolulu: University of Hawai'i Press. pp. 19-42. 
Rumsey, A and J. Weiner. 2001. Emplaced Myth: space, narrative, and knowledge in Aboriginal Australia and Papua New Guinea. Honolulu: University of Hawai'i Press.

Taylor, John P. 2003. 'Ways of the Place: history, cosmology and material culture in North Pentecost, Vanuatu.' Unpublished PhD thesis, The Australian National University.

Thomas, Nicholas. 1991. Entangled Objects: exchange, material culture, and colonialism in the Pacific. Massachusetts and London: Harvard University Press.

Tryon, D. 1996. 'Dialect chaining and the use of geographical space.' In J. Bonnemaison et al. (eds), Arts of Vanuatu, Bathurst, N.S.W: Crawford House Publishing. pp. 170-81.

Wagner, Roy. 1986. Asiwinarong: ethos, image, and social power among the Usen Barok of New Ireland. Princeton: Princeton University Press.

Walsh, D. 1966. 'The Phonology and Phrase Structure of Raga.' Masters thesis, Auckland University, Auckland.

Walsh, D.S. and W. Hadye Lini. 1981. 'Veveven bwatun tauvwa, ata la vanua Raga: a story about the beginning of creation, from Raga Island.' In H.J. and A.K. Pawley (eds), Studies in Pacific languages and cultures in honour of Bruce Biggs, Auckland: Linguistics Society New Zealand.

Wilson, C. 1932. In the Wake of the Southern Cross: work and adventures in the South Seas. London: John Murry.

Yoshioka, M. 1987. 'The story of Raga: A man's ethnography on his own society (I) the origin myth.' Journal of the Faculty of Liberal Arts (Shinshu University), 21. pp. 1-66.

Yoshioka, M. 1985. 'The marriage system of north Raga, Vanuatu.' Man and Culture in Oceania, 1. pp. 27-54.

Yoshioka, M. 1988. 'The story of Raga: A man's ethnography on his own society (II) kin relations.' Journal of the Faculty of Liberal Arts (Shinshu University), 22. pp. 19-46.

Yoshioka, M. 1993. 'The Six-section System as a Model.' Man and Culture in Oceania, 1 (9). pp. 45-68. 


\section{ENDNOTES}

1 This is a common historical theme throughout all of Vanuatu, and, for instance, provided the title to John Layard's book, Stone Men of Malekula (1942: 18-19).

2 My PhD fieldwork in this area took place over 15 months, from 1999 to 2000.

3 The prefix 'bwat' may be related to what Fox describes as 'the Proto-Austronesian term *puqun meaning "tree", "trunk", "base" or "source"' (Fox 1993: 19), and the synonymous term *batang.

4 More recent graves are also usually constructed of stone piles, but now are typically rectangular in shape as in Christian graves.

${ }^{5}$ As Codrington noted, 'Ghosts haunt especially their burial-places, and revenge themselves if offended; if a man has trespassed on the grave-place of a dead chief the ghost will smite him, and he will be sick' (1891: 288). Unlike the other more ambivalent spirits that haunt the landscape, and even though they are similarly feared, the intentions of ancestral atatun vanua are ultimately considered just.

6 Tauva was translated into Bislama as jeneresen ('generation') by Jif Ruben. It is probably related to the word tau ('to put, to make') (Yoshioka and Leona 1992: 33). This word appears in Hardacre's Dictionary as dau, with meanings including 'place', 'put', 'appoint', 'create', and 'bury'. Hardacre also lists the construction dau bwatuna, meaning 'begin' (Hardacre n.d.: 32). Note here the important connection between origin and location, or place. The appearance of Mugarimanga ('Mother clam gapes open') defines the first tauva (see discussion below). The second tauva is defined by the appearance of tavalarau - non-ancestral and invisible spirit beings (for further discussion, see Taylor 2003).

7 As the destination (or habitation) of the dead, abanoi is presently somewhat ambiguously intertwined with the Christian concept of heaven.

8 See Layard on what he calls the 'Tagaro-Qat complex' (Layard 1942: 224, 572). As Yoshioka notes (1987: 11), Bwatmahanga is clearly the North Pentecost equivalent of the Banks Islands' ancestral hero Qat. In current Raga orthography, the letters ' $b w^{\prime}$ ' have replaced ' $q$ ', as used by Anglican missionaries until the early to mid-20th century (see also Walsh 1966). After this change, 'Qat' should therefore appear as 'Bwat' ('source', 'foundation'). See also Codrington (1891: 156-7).

${ }^{9}$ In Tevimule's text, this burden is made apparent in the character of Bwatmahanga's follower Sumbwe, for whom knowledge gained through loyalty to Bwatmahanga is as easily taken away by Tagaro (Yoshioka 1987).

${ }^{10}$ Note that spelling employed by Jif Ruben is often inconsistent (and that there is no firmly established orthography for Raga).

11 While the term alengan vanua (here spelt alen vanua) is typically translated as kastom in Bislama, most Raga speakers will ultimately suggest that the Bislama term is inadequate for describing the intimacy and full range of meanings contained within the term alengan vanua, or 'ways of the place' (see Taylor 2003).

12 Peter sadly died at his home village of Lagaronboga in 2001.

13 These are alo, vula, mahava, dodo, vivivi, tano and tahi (sun, moon, air, clouds, [unclear, but possibly meaning] rainbow, earth and sea).

14 See especially Rumsey and Weiner (2001), Goldman and Ballard (1998), also Patterson (2002).

15 Many Sia Raga people link this part of the history to the biblical flood.

16 Somewhat like the more immediately ancestral atatun vanua (discussed above), these primordial atatun vanua also act as guardians of the land. Unlike the former, they are accorded with neither direct ancestral significance nor association with specific places and are thereby viewed in much more ambivalent terms - more 'devils' than 'ghosts'. Their punishments are meted on people who offend a more general 'spirit of the earth' (vui tanonda). Since such offences are also often meted with death, atatun vanua are likewise feared and highly respected.

17 Bwatnapne appears to be an important focal point for Pentecost Island. For the Ambrymese, for instance, it is where their island was linked to Pentecost by a vine (Mary Patterson, personal communication).

18 Codrington mentions a place called Atambulu as being 'the original seat of men' in Raga (1891: 169).

19 On the small islands of Malakula, Vao and Atchin, Layard explored the topographical and conceptual divisions of society into the 'Sides' (tosan) of lodge, stone and island. He also found the linguistic category to be flourishing throughout the northern islands of Vanuatu (Layard 1942: 168). In the diffusionist style of his forebears, Morgan (1877), Codrington (1891) and Rivers (1914), he concluded that this provided further evidence for the theory of matrilineal primacy in the region (Layard 1942: 169; and 
see Allen 1981, 2000). Patterson (1976) also discusses northern Vanuatu ideas of complementary opposition. She notes that the Ambrym term tali viung means 'one side of a bunch of coconuts'. Here the emphasis is patrilineal rather than matrilineal: 'a man and his father and a man and his son are 'tali viung'. ... Likewise, a woman and her father's sister and a woman and her brother's daughter are 'tali viung', but not a woman and her children.' She also makes the important point that such terms do not in fact pertain to the definition of categories or groups as such, but rather express the relationship between categories (Patterson 1976: 90-3).

20 Hardacre's definition of tavalui is 'a side, one of two parts' (Hardacre n.d.: 87).

21 See Crowe (1990: 89-95) for a discussion of left hand/right hand distinctions vis-a-vis what he describes as broader 'dualistic, twinning aspects of the Melanesian World', and northern Vanuatu in particular.

22 Also noted by Rivers (1914 Vol. 1: 190).

23 As we have seen, some creation histories recall that clams, talai, or other shellfish are the source of human origins.

24 Marital separations do infrequently occur on Pentecost.

25 Note here the different spelling of the word tauvwa from that given above (tauva).

26 For instance, note the story's contemporaneity with John Leo Tamata's father's acquisition of the name Vira Lin Tuturani.

27 See, for instance, the story of Bwatmahanga's death, as told by David Tevimule (Yoshioka 1987).

28 See especially the collection of essays in Origins, Ancestry and Alliance: Explorations in Austronesian ethnography, and the association between topography and anthropological ideas of 'precedence' within Indonesian anthropology (Fox and Sather 1996). Also Rival (1998) and Rumsey (2001). 